\title{
SENGKETA MEREK TERDAFTAR DI DIREKTORAT JENDERAL HAK KEKAYAAN INTELEKTUAL BERDASARKAN UNDANG-UNDANG NOMOR 20 TAHUN 2016 TENTANG MEREK DAN INDIKASI GEOGRAFIS
}

\author{
oleh: \\ Rizal Nugraha \\ Hana Krisnamurti,
}

\begin{abstract}
ABSTRAK
Pendaftaran atas merek merupakan salah satu bentuk perlindungan dari UndangUndang Merek, karena sistem yang digunakan di Indonesia adalah first to file principle, siapa yang mendaftar pertama maka yang bersangkutan berhak atas merek tersebut dan akan mendapatkan hak esklusifnya dengan konsekuensi tidak ada seorangpun yang boleh menggunakan merek tersebut untuk kepentingan komersial dari hak ekslusif tersebut tanpa seizin pemilik atau pemegang hak merek. Permasalahan dalam skripsi ini adalah Bagaimanakah analisis terhadap sengketa merek terdaftar di Direktorat Jenderal Hak Kekayaan Intelektual berdasarkan Undang-Undang Nomor 20 Tahun 2016 Tentang Merek dan Indikasi Geografis dan bagaimana Upaya penanggulangan sengketa merek berdasarkan Undang-Undang Nomor 20 Tahun 2016 Tentang Merek dan Indikasi Geografis. Hasil dari penelitian ini adalah bahwa Pada sengketa merek "Mawar Super Laundry" dan "Logo Superman" di mana pihak pendaftar pertama berhak mendapatkan perlindungan hukum sebagaimana dalam pasal 3 Undang-Undang Nomor 20 Tentang Merek dan Indikasi Geografis dan sesuai dengan Sistem pendaftar first to file principle dan upaya penanggulangan terhadap sengketa merek dapat dilakukan dengan 2 upaya yaitu represif dan preventif. Represif dapat dilakukan dengan cara pendaftaran ke Direktorat Jenderal Hak Kekayaan Intelektual sedangkan preventif dapat dilakukan melalui cara gugatan keperdataan, tuntutan pidana, dan melalui administratif.
\end{abstract}

\section{PENDAHULUAN}

\section{Latar Belakang}

Pasal 28 Huruf D Undang-Undang Dasar 1945 menyatakan:Setiap orang berhak atas pengakuan, jaminan, perlindungan, dan kepastian hukum yang adil serta perlakuan yang sama dihadapan hukum.Maknanya : setiap orang berhak atas pengakuan dalam arti diakui oleh negara, jaminan dan perlindungan dari negara itu sendiri serta perlakuan yang sama dihadapan hukum. Ketentuan tersebut sejalan dengan Undang-undang Nomor 20 tahun 2016 Tentang Merek dan Indikasi Geografis yakni terdapat pada Pasal 3 yang dimaksud dengan "hak atas merek diperoleh setelah merek tersebut terdaftar" dan selanjutnya dijelaskan pula soal penjelasan merek itu ditolak pada Pasal 21 ayat 1 yang dimaksud dengan "permohonan ditolak jika merek tersebut mempunyai persamaan dalam pokoknya atau keseluruhannya" adalah kemiripan yang disebabkan oleh adanya unsur yang dominan antara merek yang satu dengan merek yang lain sehingga menimbulkan kesan adanya persamaan, baik mengenai bentuk, cara penempatan, cara penulisan atau kombinasi antara unsur, maupun persamaan bunyi ucapan, yang terdapat dalam merek tersebut.

Pada intinya Hak Kekayaan Intelektual adalah hak untuk menikmati secara ekonomis hasil dari suatu kreativitas intelektual. Objek yang diatur dalam Hak Kekayaan Intelektual adalah karya-karya yang timbul atau lahir karena kemampuan intelektual manusia.Dewasa ini perkembangan hukum mengenai Hak Atas Kekayaan Intelektual (HKI) 
sering juga disebut Hak Milik Intelektual (Intellectual Property) semakin mendapat perhatian masyarakat, semakin hari orang semakin menghargai karya cipta penemuan orang lain maka Hak Kekayaan Intelektual sebuah penghormatan dan penghargaan atas hasil kerja orang lain. ${ }^{1)}$

Hak Atas Merek merupakan lingkup Hak Atas Kekayaan Intelektual karena hak atas merek sebagai hak untuk memakai tanda atau merek guna membedakan suatu produk dagang seseorang dengan produk dagang orang lain, walaupun tidak memiliki unsur pokok seperti yang diartikan dengan pengertian milik intelektual, yaitu tidak ada unsur usaha intelektual dalam bentuk penciptaan atau penemuan.

Merek sebagai bagian dari hak milik Intelektual tidak terlepas dari pemahaman bahwa hak merek diawali dari temuan-temuan dalam bidang Hak Kekayaan Intelektual lainnya, misalnya hak cipta.Pada merek ada unsur ciptaan, misalnya design logo atau huruf. Ada hak cipta dalam bidang seni, namun dalam hak merek bukan hak cipta dalam bidang seni yang dilindungi tetapi mereknya itu sendiri dan hak merek itu terbatas hanya pada penggunaan atau pemakaiannya pada produk-produk yang dipasarkan dan mengandung nilai ekonomis.

Merek adalah sesuatu ( gambaran atau nama ) yang dapat digunakan untuk mengidentifikasi suatu produk atau perusahan di pasaran. Pengusaha biasanya berusaha mencegah orang lain menggunakan merek mereka karena dengan menggunakan merek, para pedagang memperoleh reputasi baik dan kepercayaan dari para konsumen serta dapat membangun hubungan antara reputasi tersebut dengan merek yang telah digunakan perusahaan secara regular. Semua hal di atas tentunya memutuhkan pengorbanan waktu, tenaga dan uang. ${ }^{2)}$

Merek sangat penting dalam dunia periklanan dan pemasaran karena publik sering mengaitkan suatu kualitas atau reputasi barang dan jasa dengan merek tertentu. Sebuah merek dapat menjadi kekayaan yang sangat berharga secara komersial. Merek suatu perusahaan seringkali lebih bernilai dengan aset riil perusahaan tersebut. Merek juga berguna untuk para konsumen. Para konsumen membeli produk tertentu ( yang terlihat dalam mereknya ) karena menurut mereka, merek tersebut berkualitas tinggi atau aman untuk di konsumsi dikarenakan reputasi dari merek tersebut. Jika sebuah perusahaan menggunakan merek perusahaan lain, para konsumen mungkin merasa tertipu karena telah membeli produk dengan kualitas yang lebih rendah.

Pendaftaran atas merek merupakan salah satu bentuk perlindungan dari UndangUndang Merek, karena sistem yang digunakan di Indonesia adalah first to file principle, siapa yang mendaftar pertama maka yang bersangkutan berhak atas merek tersebut dan akan mendapatkan hak esklusifnya dengan konsekuensi tidak ada seorang pun yang boleh menggunakan merek tersebut untuk kepentingan komersial dari hak ekslusif tersebut tanpa seizin pemilik atau pemegang hak merek.

Ketentuan Undang-undang Nomor. 20 Tahun 2016 tentang Merek dan Indikasi Geografis lanjut apa saja yang tidak dapat dijadikan suatu merek atau yang tidak dapat didaftarkan sebagai suatu merek. Berdasarkan Pasal 20 Undang-undang Nomor. 20 Tahun 2016 Tentang Merek dan Indikasi Geografis tidak dapat didaftarkan apabila mengandung salah satu unsur di bawah ini:

1. Bertentangan dengan ideologi negara, peraturan perundang-undangan, moralitas, agama, kesusilaan, atau ketertiban umum; 2017, hlm 1

1) Mujiyono ferianto, "memahami dan cara memperoleh hak kekayaan intelektual", Yogyakarta,

2)Tim Lindsey ( et al ), hak kekayaan intelektual Suatu Pengantar, Asian Law Group pty. \& Penerbit P.T. Alumni,Bandung 2006, hlm 131 
2. Sama dengan, berkaitan dengan, atau hanya menyebut barang dan/atau jasa yang dimohonkan pendaftarannya;

3. Memuat unsur yang dapat menyesatkan masyarakat tentang asal, kualitas jenis, ukuran, macam, tujuan penggunaan barang dan/atau jasa yang dimohonkan pendaftarannya atau merupakan nama varietas tanaman yang dilindungi untuk barang dan/atau jasa yang sejenis;

4. Memuat keterangan yang tidak sesuai dengan kualitas, manfaat, atau khasiat dari barang dan/atau jasa yang diproduksi;

5. Tidak memiliki daya pembeda; dan/atau

6. Merupakan nama umum dan/atau lambang milik umum

Pasal 21 Ayat 2 Undang-undang Nomor 20 Tahun 2016 Tentang Merek dan Indikasi Geografis juga memuat tentang penolakan pendaftaran merek yaitu:

1. Merupakan atau menyerupai nama atau singkatan nama orang terkenal, foto, atau nama badan hukum yang dimiliki orang lain, kecuali atas persetujuan tertulis yang berhak;

2. Merupakan tiruan atau menyerupai nama atau singkatan nama, bendera, lambang atau simbol atau emblem suatu negara, atau lembaga nasional maupun internasional, kecuali atas persetujuan tertulis dari pihak yang berwenang; atau

3. Merupakan tiruan atau menyerupai tanda atau cap atau stempel resmi yang digunakan oleh negara atau lembaga pemerintah, kecuali atas persetujuan tertulis dari pihak yang berwenang.

Pasal 3 Undang-Undang Merek dan Indikasi Geografis, menyatakan bahwa hak atas merek diperoleh setelah merek tersebut terdaftar. Dengan kata lain, diperolehnya hak atas merek adalah sebagai satu konsekuensi telah didaftarkan merek tersebut pada Kantor Direktorat Jenderal Hak Kekayaan Intelektual. Pendaftaran adalah syarat mutlak bagi seseorang jika merek tersebut diakui secara sah bahwa ia adalah pemilik dari merek tersebut. Tanpa pendaftaran, maka tidak Perlindungan merek tersebut dan juga perlindungan yang diberikan atas merek tersebut.

Pemilik merek terdaftar dapat mengajukan gugatan kepada Pengadilan Niaga terhadap pihak lain yang secara tanpa hak menggunakan merek yang mempunyai persamaan pada pokoknya atau keseluruhannya untuk barangatau jasa yang sejenis berupa gugatan ganti rugidan/ataupenghentian semua perbuatan yang berkaitan dengan penggunaan merek tersebut.

Pasal 1 ayat 1 Undang-Undang Nomor 20 Tahun 2016 Tentang Merek dan Indikasi Geografis, mengidentifinisikan merek sebagai sebuah tanda yang terdiri dari :

a. Gambar

b. Nama

c. Kata

d. Huruf-huruf

e. Angka-angka

f. Susunan warna

g. Atau kominasi dari unsur-unsur tersebut yang memiliki daya perbeda dan digunakan dalam kagiatan perdagangan barang atau jasa.

Mencari perlindungan atas bentuk dan gaya ( style ) dari tampilan/bungkus produk yang dihasilkan sebuah perusahan adalah hal yang perlu diperhatikan oleh para pemilik 
merek dari produk tersebut. Tindakan perlindungan atas tampilan dari suatu produk juga akan membantu menindak pihak lain yang meniru tampilan produk tersebut tanpa izin.

Pada dasarnya sebuah merek memiliki persyaratan untukdidaftarkan. Sistem administrasi merek begitu penting karena hak atas merek adalah hak khusus yang diberikan oleh pemerintah atau negara kepada pemilik merek untuk menggunakan merek tersebut atau memberi izin pihak lain untuk menggunakannya, karena itu merek harus didaftarkan di Direktorat Jenderal Hak Kekayaan Intelektual. Pendaftaran sangat penting artinya bagi konsumen, karena konsumen akan membeli merek (cap, simbol, lambang, dan sebagainya) yang tentunya memiliki kualitas dan aman untuk dikonsumsi. ${ }^{3)}$

Merek yang tidak dapat didaftarkan yaitu merek yang bertentangan dengan kesusilaan dan ketertiban umum, tanda-tanda yang tidak mempunyai daya pembeda, tanda atau kata milik umum, dan merupakanketerangan atau berkaitan dengan barang atau jasa yang akan didaftarkan. Syarat mutlak suatu merek harus dipenuhi oleh setiap orang atau badan hukum yang ingin memakai sebuah merek yaitu bahwa merektersebut harus mempunyai daya pembeda yang cukup. Dengan kata lain,tanda yang dipakai harus sedemikian rupa, sehingga mempunyai cukupkekuatan untuk membedakan barang hasil produksi seseorang dengan barang hasil produksi orang lain. ${ }^{4)}$

Pada kasus sengketa merek, Siti Wardah yang berinisiatif mendaftarkan merek produk cairan pembersihnya mawar super laundry berikut logonya ke Direktorat Jenderal Hak Kekayaan Intelektual, akan tetapi permohonan pendaftaran merek ditolak. Melalui surat tertanggal 26 Maret 2018, Direktorat Jenderal Hak Kekayaan Intelektual. Pendaftaran ditolak dikarenakan merek mawar super laundry sudahlebih dulu terdaftar di Direktorat Jenderal Hak Kekayaan Intelektual atas nama Siti Hardita Sundari. Pihak penggugat Siti wardah mengajukan gugatan pembatalan merek mawar super laundry dilakukan dengan itikad tidak baik dan tidak jujur, gugatan itu didaftarkan di pengadilan niaga Jakarta, pada putusan pertama pengadilan niaga dimenangkan oleh penggugat atas nama Siti wardah akan tetapi pada pasal 3 Undang-Undang Nomor 20 Tahun 2016 Tentang Merek dan Indikasi Geografis menyatakan " Hak atas Merek diperoleh setelah merek tersebut terdaftar ", dan pendaftaran merek di Indonesia menganut asas first to file artinya siapa yang mengajukan merek terlebih dahulu maka dianggap sebagai pemegang merek.

\section{Identifikasi Masalah}

1. Bagaimanakah analisis terhadap sengketa merek terdaftar di Direktorat Jendral Hak Kekayaan Intelektual berdasarkan Undang-Undang Nomor 20 Tahun 2016 Tentang Merek dan Indikasi Geografis?

2. Bagaimanakah upaya penanggulangan engketa merek berdasarkan Undang-Undang Nomor 20 Tahun 2016 Tentang Merek dan Indikasi Geografis.

${ }^{3}$ Suyud Margono, , Hak Milik Industri: Pengaturan dan Praktik di Indonesia, GhaliaIndonesia, Bogor, 2011, hlm. 79

4) Ibid, hlm 67 


\section{TINJAUAN PUSTAKA}

\section{Pengertian Hak Kekayaan Intelektual}

Hak Kekayaan Intelektual, disingkat "HKI" , adalah padanan kata yang biasa digunakan untuk Intellectual Property Rights (IPR), yakni hak yang timbul bagi hasil otak yang menghasilkan suatu produk atau proses yang berguna untuk manusia. ${ }^{5)}$

Hak kekayaan intelektual muncul dari cipta, rasa, karsa, dankarya manusia, atau dapat pula disebut sebagai hak atas kekayaaan yanglahir dari kemampuan intelektualitas manusia. Atas hasil kreasitersebut, maka individu, kelompok, atau perusahaan yang menciptakan memiliki hak yang dijamin dan dilindungi peraturan yang ada untukmenggunakannya dan mengambil keuntungan atas hasil kreasinyatersebut.

Karya-karya tersebut dilahirkan atau dihasilkan atas kemampuanintelektual manusia melalui curahan waktu, tenaga, pikiran, daya cipta,rasa dan karsanya. Hal tersebut yang membedakan kekayaan intelektualdengan jenis kekayaan lain yang juga dapat dimiliki oleh manusia tetapitidak dihasilkan oleh intelektualitas manusia. Sebagai contoh, kekayaanalam berupa tanah dan atau tumbuhan yang ada di alam merupakanciptaan dari sang Pencipta. Meskipun tanah dan atau tumbuhan dapatdimiliki oleh manusia tetapi tanah dan tumbuhan bukanlah hasil karyaintelektual manusia.

Ciri khas Hak Kekayaan Intelektual sebagai hak privat (private rights). Seseorang bebas untuk mengajukan permohonan atau mendaftarkan karya intelektualnya atau tidak. Hak eksklusif yang diberikan Negara kepada individu pelaku Hak Kekayaan Intelektual (inventor, pencipta, pendesain dan sebagainya) tiada lain dimaksudkan sebagai penghargaan atas hasil karya (kreativitas)nya dan agar orang lain terangsang untuk dapat lebih lanjut mengembangkannya lagi, sehingga dengan sistem Hak Kekayaan Intelektual tersebut kepentingan masyarakat ditentukan melalui mekanisme pasar.

Sistem Hak Kekayaan Intelektual juga menuntut diadakannya sistem dokumentasi yang baik atas segala bentuk kreativitas manusia sehingga kemungkinan dihasilkannya teknologi atau hasil karya lainnya yang sama dapat dihindarkan/dicegah. Dengan dukungan dokumentasi yang baik tersebut, diharapkan masyarakat dapat memanfaatkannya dengan maksimal untuk keperluan hidupnya atau mengembangkannya lebih lanjut untuk memberikan nilai tambah yang lebih tinggi lagi.

Perlindungan hukum terhadap Hak Kekayaan Intelektual (HKI) semakin menjadi perhatian negara maju sering kemajuan sektor ekonomi kreatif dan ekonomi digital. Banyak negara yang miskin sumber daya alam sukses bertransformasi menjadi negara maju berkat keberhasilan mengembangkan Hak Kekayaan Intelektual dan ekonomi kreatif. Hak Kekayaan Intelektual bisa dikembangkan menjadi bisnis waralaba (Franchise) sehingga dapat melipatgandakan omzet bisnis dan memberikan dampak berganda (multiplier effect) pada bidang bisnis lainnya. Beberapa subsektor ekonomi kreatif (seperti film,acara televisi, kuliner, dan lain-lain) juga dapat dikembangkan menjadi model bisnis waralaba. Dimasa kini, kekuatan ide/gagasan lebih menonjol dibandingkan kekuatan materi dan kekuasaan. Ide cerdas yang berwujud dalam bentuk ciptaan baru, inovasi baru dan desain baru bisa mengubah peradaban manusia. Sejarah manusia membuktikan betapa dahsyat peran individu-individu yang kreatif dan inovatif dalam mengubah peradaban dan kebudayaan. Hal inilah yang mendorong negara-negara maju sangat peduli pada perkembangan Hak Kekayaan Intelektual dan ekonomi kreatif. Jika punya daya kreasi dan

5) Daniel Suryana,Sejarah dan Perkembangan Hak Kekayaan Intelektual Indonesia, dansur, Jakarta, 2001, hlm 13 
inovasi, maka dunia bisa berada digengaman tangan kita. Kitapun bisa mengubah dunia tanpa harus menjadi superhero ala komik Marvel. ${ }^{6}$ )

Hak Kekayaan Intelektual terdiri atas Hak Cipta, Paten, Merek, Desain Industri, Desain Tata Letak Sirkuit Terpadu (DTLST), Rahasia dagang, dan Perlindungan Varietas Tanaman (PVT). HKI tergolong benda bergerak yang dapat dijadikan jaminan utang melalui skema Gadai dan Fidusia. Hak Kekayaan Intelektual yang berwujid nyata (material) dan bersifat benda (tangible) dapat diikatdengan jaminan Gadai dan Fidusia. Sedangkan Hak Kekayaan Intelektual yang taknyata (immaterial) dan takbenda (intangible) hanya dapat diikat dengan fidusia. ${ }^{7)}$

Hak Kekayaan Intelektual juga melindungi merek ( sebagai contoh nama dan/atau simbol yang digunakan oleh sebuah perusahaan), yang telah dikembangkan oleh perusahaan untuk melambangkan reputasi mereka dan menempatkannya ke dalam pasar. Jika oranglain menggunakan merek tersebut, konsumen mungkin berfikir bahwa mereka sedang membeli sesuatu yang dibuat oleh perusahaan yang telah menemukan merek tersebut. Ini berarti bahwa perusahaan yang telah menciptakan merek yang bersangkutan dapat menderita kerugian. Hukum Hak Kekayaan Intelektual mengizinkan perusahaan untuk menuntut orang-orang yang telah meniru merek mereka tanpa izin.

Hak Kekayaan Intelektual terdiri dari :

1. Hak cipta dan hak terkait

2. Merek dagang

3. Indikasi geografis

4. Desain industri

5. Paten

6. Tata letak : (topografi) sirkuit terpadu

7. Perlindungan informasi rahasia

8. Kontrol terhadap praktek persaingan usaha tidak sehat dalam perjanjian lisensi. ${ }^{8)}$

Hak Kekayaan Intelektual pada umumnya berhubungan dengan perlindungan penerapan ide dan informasi yang memiliki nilai komersial. Hak Kekayaan Intelektual adalah kekayaan pribadi yang dapat dimiliki dan diperlakukan dama dengan bentuk-bentuk kekayaan lainnya.

Kekayaan Intelektual dapat diperjualbelikan seperti sebuah buku. Hak Kekayaan Intelektual dapat juga disewakan selama kurun waktu tertentu dimana pihak penyewaan membayar sejumlah uang kepada pihak yang menyewakan hak tersebut untuk menggunakan kekayaan intelektual tersebut. Perjanjian seperti ini disebut 'lisensi' dan akan dibahas lebih lanjut dalam buku ini.

Hukum Hak Kekayaan Intelektual tidak diperluas terhadap setiap situasi dimana seseorang melakukan usaha atau sumber daya ke dalam sesuatu yang melibatkan pengeluaran akal budi, pengetahuan, keahlian atau tenaga. Berdasarkan hukum Indonesia dan undang-undang di banyak negara, ciptaan dan invensi hanya akan dilindungi jika ciptaan dan invensi tersebut memenuhi sayarat-sayarat tertentu yang telah diatur oleh undang-undang. hlm 1-2

16) Iswi hariyanti (et al), Hak Kekayaan Intelektual Sebagai Jaminan kredit, Andi yogyakarta, 2018,

17) Ibid, hlm 6

18) Tim lindsey (et al), Hak Kekayaan Intelektual Suatu Pengantar, P.T. Alumni, Bandung 2006, hlm 
Merek Pendaftaran sebuah merek yang digunakan untuk mengidentifikasi barang dan jasa yang di produksi atau didistribusikan oleh sebuah perusahaan tertentu memberikan hak kepada perusahaan tersebut untuk menggunakan secara ekslusif merek tersebut. Pemilik merek terdaftar memeliki hak untuk mencegah pihak lain menggunakan mereknya tanpa izin. Merek sering merupakan logo yang terkenal dan menjadi komoditi yang sangat bernilai misalnya levis jeans, baju Gucci atau jam Rolex. Membangun hubungan antara produk dan usaha menciptakan reputasi yang bernilai atau 'nama baik' (good will) merupakan dasar dari kebanyakan perdagangan internasional.

Merek yang diinvestasikan melalui periklanan dan promosi adalah sangat bernilai. Sebagai contoh merek coca-cola bernilai sekitar (\$ 39 miliyar). Beberapa orang mungkin berargumen bahwa coca-cola itu sendiri rasanya sama dengan minuman cola berkolaborasi lainnya, dan coca-cola menjadi lebih terkenal hanya karena orang, yang dipengaruhi oleh periklanan dan promosi, membeli coca-cola untuk namanya (atau mereknya).Inilah mengapa banyak perusahaan beusaha untuk melindungi penggunaan ekslusif dari merek mereka dan mengapa pembajakan atau penipuan terhadap penggunan merek menjadi beegitu umum. Beberapa negara enggan menyediakan perlindungan yang efektif bagi merek-merek terkenal. Ini karena kebanyakan dari merek-merek tersebut dimiliki oleh perusahaan-perusahaan di negara-negara maju dan negara-negara berkembang melihat hal ini sebagai mengalirnya modal keluar dari negara-negara miskin di belahan selatan ke masyarakat maju di bagian utara. ${ }^{9}$

\section{Ruang Lingkup Hak Kekayaan Intelektual}

Pengertian mengenai Hak Kekayaan Intelektual dalam hukum Anglo Saxon dikenal istilah hukumIntelectual Property Rights. Istilah hukum tersebut diterjemahkan kedalam bahasaIndonesia menjadi 2 macam istilah hukum: Hak Milik Intelektual dan Hak KekayaanIntelektual (HKI). Perbedaan terjemahan terletak pada kata property. Kata tersebutmemang dapat diartikan sebagai kekayaan, dapat juga sebagai milik. Bila berbicaratentang kekayaan selalu tidak lepas dari milik, dan sebaliknya berbicara tentang milikproperty tidak terlepas dari kekayaan.

Hak kekayaan intelektual adalah hak milik hasil pemikiran (intelektual) yang melekat pada pemiliknya, bersifat tetap dan eksklusif. Hak kekayaan intelektual merupakan serangkaian hak dan kepentingan yang sah terkait dengan produk yang dihasilkan dari aktivitas intelektual manusia. Hak kekayaan intelektual adalah hak yang berasal dari kegiatan kreatif suatu kemampuan daya pikir manusia yang diekspresikan kepada khalayak umum dalam berbagi bentuknya, bermanfaat, berguna untuk menunjang kehidupan dan memiliki nilai ekonomi.Hak kekayaan intelektual merupakan hak privat (private rights) dan memilikikeistimewaan tersendiri dibanding hak perdata lainnya. Keistimewaannya yakni padasifat eksklusifnya. Hak kekayaan intelektual hanya diberikan dan berlaku kepadapemiliknya, si pencipta, penemu ataupun pemegang karya intelektual lainnya. Pihakmana pun dilarang untuk meniru, memakai dan mempergunakan dalam perdagangansuatu karya intelektual tanpa seizin pemiliknya. Ekslusivitas hak kekayaan intelektualmemberi hak paling unggul kepada pemiliknya.Hak kekayaan intelektual merupakan bagian dari harta kekayaan (kebendaan).

Hartakekayaan adalah benda milik orang atau badan yang memiliki nilai ekonomi, diakuidan dilindungi oleh hukum berdasarkan bukti yang sah, serta dapat dialihkan kepadapihak lain, baik karena perjanjian maupun karena Undang-Undang.

${ }^{9)} \mathrm{Ibid}, \mathrm{hlm}$ 6-8 
Perlindungan hak kekayaan intelektual lebih dominan pada perlindunganindividu namun untuk menyeimbangkan antara kepentingan individu dengankepentingan masyarakat, maka hak kekayaan intelektual mendasarkan diri padaprinsip sebagai berikut:

a. Prinsip Keadilan The Principle of Natural Justice

Hukum memberikan perlindungan kepada pencipta sebuah karya berupa imbalanbaik materi atau bukan materi seperti adanya rasa aman dilindungi dan diakuiatas hasil karyanya atau yang disebut hak;

b. Prinsip ekonomi The Economy Argument

Hak Kekayaan intelektual merupakan hak yang berasal dari kegiatan yang kreatifdari suatu kemampuan daya pikir manusia yang diekspresikan kepada khalayakumum yang bersifat ekonomis yang bertujuan mencari keuntungan;

c. Prinsip Kebudayaan The Cultural Argument

Pengakuan atas kreasi, karya, cipta manusia yang dibakukan dalam system HakKekayaan Intelektual adalah suatu usaha yang tidak dapat dilepaskan sebagaiperwujudan suasana yang diharapkan mampu membangkitkan semangat dan minat melahirkan ciptaan baru,

d. Prinsip sosial The Social Argument

Hukum tidak mengatur kepentingan manusia sebagai perseorangan yang berdirisendiri, terlepas dari manusia yang lain akan tetapi hukum mengatur kepentinganmanusia sebagai warga masyarakat. ${ }^{10}$

Penggolongan hak kekayaanintelektual digolongkan dalam dua ruang lingkup, Hak Cipta (Copy Rights) dan HakKekayaan Industri (Industrial Property Rights) yang terdiri dari Merek (Trade Mark),Paten (Patens), Rahasia Dagang (Trade Secret), Desain Industri (Industrial Design),serta Desain Tata Letak Sirkuit Terpadu (Layout Design Topographics of IntegrationCircuits), kemudian Perlindungan Varietas Tanaman (Plant Variety). Mengingatmerek digunakan dalam dunia usaha perdagangan dan industri, sehingga hak atasmerek digolongkan dalam ruang lingkup hak kekayaan industri (Industrial PropertyRights). Di bawah pengawasan Direktorat Jendral Hak Kekayaan IntelektualKementrian Hukum.

\section{Pengertian Umum Tentang Merek}

Merek adalah salah satu asset yang sangat berharga bagi sebuah perusahaan. Dengan merek yang diseleksi dan dipelihara secara baik,sebuah perusahaan dapat menjalankan dan mengembangkan bisnisnya.Perlindungan hukum yang memadai di bidang merek akan sangatberpengaruh bagi kelangsungan sebuah perusahaan dan sekaligusmeningkatkan daya saing di pasar global dan nasional. ${ }^{11)}$

Istilah merek sejauh ini diartikan dengan berbagai cara, tergantungpada perspektif pemahaman atas fenomena merek itu sendiri. Dalam artiklasik, merek dihubungkan dengan identifikasi sebuah produk danpembedaannya dari produk-produk para pesaing, baik dalam bentukpemakaian nama tertentu, logo spesifik, desain khusus, maupun tanda dan simbol visual lainnya. ${ }^{12)}$

20) Pipin Syarifin, Peraturan Hak Kekayaan Intelektual di Indonesia, Pustaka Bani Quraisy, Bandung, 2004, hlm. 11-12.

11) Tomi Suryo Utomo, Hak Kekayaan Intelektual di Era Global, Graha Ilmu, Yogyakarta, 2010, hlm 209

${ }^{12)}$ Casavera, 15 Kasus Sengketa Merek di Indonesia, Graha Ilmu, Yogyakarta, 2009, hlm 3 
Pasal 1 angka 1 Undang-Undang Nomor 20 Tahun 2016 tentang Merek dan Indikasi Geografis memberikan pengertian bahwa Merek adalah tanda yang dapat ditampilkan secara grafis berupa :

1. Gambar

Gambar yang dijadikan logo merek tidak boleh terlalu rumit seperti benang kusut atau juga terlalu sederhana seperti titik. Sehingga, gambar dapat melambangkan kekhususan tertentu dalam bentuk lencana atau logo, dan secara visual langsung memancarkan identitas merek tersebut.

2. Nama

Pada dasarnya nama orang, badan usaha, kota, benda, dapat dijadikan sebagai Merek namun tetap harus memiliki daya pembeda (distinctive power) yang kuat agar dapat menjadi identitas yang sangat spesifik dari pemilik nama. Nama yang sangat umum yang tidak memiliki daya pembeda yang kuat tidak dapat didaftarkan sebagai Merek karena akan mengaburkan identitas khusus seseorang dan membuat bingung masyarakat. Begitu pula dengan nama yang mempunyai lebih dari satu pengertian tidak bisa dijadikan Merek.

3. Kata

Kata dapat dijadikan sebagai Merek jika mempunyai kekhususan yang memberikan kekuatan daya pembeda dari Merek lain yang meliputi berbagai bentuk yaitu:

a. Dapat merupakan kata dari bahasa asing, bahasa Indonesia, dan bahasa daerah.

b. Dapat berupa kata sifat, kata kerja, dan kata benda.

c. Dapat meerupakan kata yang berasal dari istilah bidang tertentu, seperti budaya, pendidikan, kesehatan, teknik, olahrahraga, seni, dan sebagainya.

d. Bisa merupakan suatu kata saja atau lebih dari satu kata, dua atau beberapa kata.

4. Huruf

Sama halnya dengan gambar, sepanjang tidak memuat susunan yang rumit dan tidak terlalu sederhana, huruf juga dapat dijadikan Merek.

5. Angka

Angka tidak dapat dijadikan sebagai Merek jika hanya mengandung satu angka saja karena terlalu sederhana dan tidak memiliki daya pembeda yang cukup. Oleh karena itu, angka harus dibuat sedemikian rupa hingga memiliki daya pembeda, namun tidak terlalu rumit juga karena akan sulit didefinisikan sehingga tidak dapat didaftarkan sebagai Merek.

6. Susunan Warna

Merek yang berupa susunan warna berarti Merek tersebut terdiri dari satu unsur warna. Susunan warna yang dibuat sederhana tanpa dikombinasikan dengan unsur gambar atau lukisan geometris, diagonal atau lingkaran, atau gambar dalam bentuk apa saja, dianggap kurang memberikan daya pembeda.

7. Merek Kombinasi

Merek kombinasi merupakan unsur Merek yang terdiri dari gabungan gambar, nama, kata, huruf, angka serta susunan warna yang secara keseluruhan tidak merupakan satu kesatuan pengertian sendiri. Banyak Merek-Merek yang berbentuk kombinasi dari berbagai unsur. Bahkan, pada umumnya hampir semua Merek merupakan kombinasi dari dua, tiga, atau seluruh unsur-unsur tersebut. 
Pada hakikatnya merek ada suatu tanda. Akan tetapi, agar tandatersebut dapat diterima sebagai merek, harus memiliki daya pembeda. Yang dimaksudkan dengan memiliki daya pembeda adalah memiliki kemampuan untuk digunakan sebagai tanda yang dapat membedakan hasil perusahaan yang satu dengan perusahaan yang lain. Suatu merek haruslah mempunyai sifat yang khas dan yang lain dari yang lain.

Hak atas merek adalah hak khusus yang diberikan pemegang kepada pemilik merek, untuk menggunakan merek tersebut atau memberikan izin untuk menggunakannya kepada orang lain. Berbeda dengan hak cipta, merek harus didaftarkan terlebih dahulu didalam daftar umum merek.

Merek sangat penting dalam dunia periklanan dan pemasaran karena publik sering mengaitkan suatu imej, kulitas atau reputasi barang dan jasa dengan merek tertentu. Sebuh merek dapat menjadi kekayaan yang sangat berharga secara komersial. Merek suatu perusahaan seringkali lebih bernilai dibandingkan dengan aset rill perusahaan tersebut.

Merek juga berguna untuk para konsumen. Merek membeli produk tertentu (yang terlihat dari mereknya) karena menurut mereka, merek tersebut berkualitas tinggi atau aman untuk dikonsumsi reputasi dari merek tersebut jika sebuah perusahaan menggunakan merek perusahaan lain, para konsumen mungkin merasa tertipu karena telah membeli produk dengan kualitas yang lebih rendah. ${ }^{13)}$

\section{Perlindungan Terhadap Pemegang Hak Merek}

Perlindungan hukum merek yang diberikan baik kepada merek asing atau lokal, terkenal atau tidak terkenal hanya diberikan kepada merek yang terdaftar. Untuk itu setiap pemilik merek diharapkan agar mendaftarkan mereknya ke Direktorat Jendral Hak Kekayaan Intelektual agar dapat memperoleh perlindungan hukum terhadap mereknya. Merek terdaftar mendapat perlindungan hukum untuk jangka waktu 10 (sepuluh) tahun dan berlaku surut sejak tanggal penerimaan permohonan merek bersangkutan. Atas permohonan pemilik merek jangka waktu perlindungan merek terdaftar dapat diperpanjang setiap kali untuk jangka waktu yang sama. Perlindungan hukum berdasarkan sistem first to file principle diberikan kepada pemegang hak merek terdaftar yang 'beritikad baik' bersifat preventif maupun represif. Perlindungan hukum preventif dilakukan melalui pendaftaran merek, dan perlindungan hukum represif diberikan jika terjadi pelanggaran merek melalui gugatan perdata maupun tuntutan pidana dengan mengurangi kemungkinan penyelesaian alternatif diluar pengadilan. ${ }^{14}$

Perlindungan hukum tersebut dapat berupa perlindungan yang bersifat preventif maupun represif, yaitu sebagai berikut:

a. Perlindungan hukum bersifat preventif

Pidana atau pelanggaran hukum terhadap merek dan merek terkenal. Dalam hal ini sangat bergantung pada pemilik merek untuk mendaftarkan mereknya agar mendapat perlindungan hukum. Dalam Pasal 3 Undang-undang Merek dan Indikasi Geografis dinyatakan bahwa hak atas merek adalah hak atas merek diperoleh setelah merek tersebut terdaftar.Dengan demikian, apabila seseorang/badan hukum ingin agar mereknya mendapatkan perlindungan hukum berdasarkan hukum merek, maka merek yang bersangkutan harus terdaftar terlebih dahulu. Suatu permohonan pendaftaran merek akan diterima pendaftarannya apabila telah memenuhi

23) Ibid, hlm 131-132

${ }^{26)}$ Meli hertati gultom, “ perlindungan hukum bagi pemegang hak merek terdaftar terhadap pelanggaran merek http://library.binus.ac.id/eColls/eThesisdoc/Bab2/2012-2-00777HM\%20Bab2001.pdf (Tanggal 11, 23:17) 
persyaratan baik yang bersifat formalitas maupun substantif yang telah ditentukan Undang-undang Merek. Syarat penting yang sekaligus menjadi ciri utama suatu merek ialah adanya daya pembeda (distinctiveness) yang cukup. Merek yang dipakai haruslah sedemikian rupa sehingga mempunyai cukup kekuatan untuk membedakan barang atau jasa suatu perusahaan dengan barang atau jasa produksi perusahaan lainnya.

b. Perlindungan Hukum Represif

Perlindungan hukum yang bersifat represif dilakukan jika terjadi pelanggaran hak atas merek melalui gugatan perdata dan atau tuntutan pidana. Bahwa pemilik merek terdaftar mendapat perlindungan hukum atas pelanggaran hak atas merek baik dalam wujud gugatan ganti rugi atau penghentian semua perbuatan yang berkaitan dengan penggunaan merek tersebut maupun berdasarkan tuntutan hukum pidana melalui aparat penegak hukum. Pemilik merek terdaftar juga memiliki hak untuk mengajukan permohonan pembatalan pendaftaran merek terhadap merek yang ia miliki yang didaftarkan orang lain secara tanpa hak. Turut-sertanya Indonesia dalam era globalisasi menimbulkan tingkat persaingan yang semakin meninggi. Dalam persaingan usaha yang cukup ketat, timbul banyak kecurangan-kecurangan yang dilakukan oleh pelaku usaha untuk menjatuhkan kompetitor usahanya, misalnya dengan melakukan pemalsuan merek. Hal tersebut dapat menimbulkan kerugian bagi pemilik merek yang sebenarnya apabila kualitas yang dijual tidak sama dengan kualitas produk yang asli. Selain itu juga menimbulkan kebingungan bagi masyarakat luas.

Terkenal terutama produk dari luar negeri (label minded) juga sangat mempengaruhi dan sekaligus menguntungkan pemalsuan merek, karena mendapatkan kesempatan untuk memuaskan hasrat mesyarakat melalui merek-merek asli tapi palsu (aspal) atau merek yang mirip dengan merek terkenal, dengan menghasilkan produk yang kerap kali sengaja disesuaikan dengan kemampuan kantong kosong konsumen yang ingin mengenakan merek terkenal tetapi tidak mempunyai kemampuan untuk membelinya sehingga mereka membeli merek-merek asli tapi palsu asalkan tetap bisa gengsi. Pemakaian merek yang mirip dengan merek terkenal milik orang lain secara tidak berhak dapat menyesatkan konsumen terhadap asal-usul, dan atau kualitas barang. Pemakaian merek terkenal secara tidak sah dikualifikasi sebagai pemakaian merek yang beritikad tidak baik. Penggunaan produk dengan merekmerek tertentu disamping good will yang dimiliki oleh mereknya sendiri selain itu juga sifat fanatik dari konsumen terhadap merek tersebut yang dianggapmempunyai kelebihan atau keunggulan dari merek yang lain. Sifat fanatik yang dimiliki oleh konsumen tidak semata-mata untuk memenuhi kebutuhan saja, tetapi ada juga mengutamakan prestise dan memberikan kesan tersendiri dari pemakainya sehingga dengan memakai persepsi mereka adalah suatu "simbol" yang akan menimbulkan gaya hidup baru (life style). Adanya perbedaan persepsi didalam masyarakat mengenai merek menimbulkan berbagai penafsiran, tetapi meskipun begitu berarti bahwa tindakan orangorang yang memproduksi suatu barang dengan mendompleng ketenaran milik orang lain tidak bisa dibenarkan begitu saja, karena dengan membiarkan tindakan yang tidak bertanggung jawab maka secara tidak langsung menghasilkan dan membenarkan seseorang untuk menipu dan memperkaya diri secara tidak jujur.

Menghindari praktik-praktik yang tidak jujur dan memberikan perlindungan hukum kepada pemilik atau pemegang merek serta konsumen maka Negara mengatur perlindungan merek dalam suatu hukum merek dan selalu disesuaikan dengan perkembangan perkembangan yang terjadi di dunia perdagangan internasional yang 
tujuannya adalah mengakomodasikan semua kepentingan-kepentingan yang ada guna menciptakan suatu perlindungan hukum. ${ }^{15)}$

Secara garis besar, perlindungan hukum atas merek ditujukankepada 2 kepentingan yang seolah-olah tidak ada hubungannya satusama lain atau bahkan bertentangan, yaitu kepentingan pemilik merek(produsen) dan kepeningan konsumen. Sebenarnya, perlindungan atasmerek dagang bertujuan untuk melindungi 2 kepentingan tersebut secaraseimbang dan tidak berat sebelah. Secara menyeluruh, kepentinganyang hendak dilindungi oleh hukum merek dapat dipisahkanmenjadi 4 kelompok berikut: ${ }^{16)}$

1. Kepentingan pemilik merek untuk tidak diganggu gugat dalamhubungan baiknya dengan para konsumen, yang telah dibinaolehnya di pasar melalui penggunaan suatu merek tertentu,serta dalam harapan yang wajar untuk memperoleh langganantetap pada masa dating, yang kesemuanya itu terjamin olehpengenalan masyarakat kepada merek tersebut, yangmenunjukkan bahwa pemilik merek itu adalah produsen daribarang yang bersangkutan.

2. Kepentingan para produsen atau para pedagang lainnya yangbersaing untuk bebas memasarkan barang-barangnya denganmemakai tanda-tanda umum yang dapat dipakai oleh siapasaja, dan yang seharusnya tidak boleh dimonopoli oleh siapapun sehingga tidak merugikan kebebasan mereka untukmenjual barang-barangnya dalam persaingan jujur dan sah.

3. Kepentingan para konsumen untuk dilindungi terhadap praktik-praktikyang cenderung hendak menciptakan kesan-kesan yangdapat menyesatkan dan menipu atau membingungkan mereka,dengan cara memengaruhi pikiran mereka bahwa suatuperusahaan adalah sama dengan perusahaan lain, atau hasil-hasildari suatu perusahaan itu juga berasal dari perusahaanyang lain tersebut.

4. Kepentingan umum untuk memajukan perdagangan yang jujurdi pasar-pasar, serta untuk mencegah timbulnya praktik-praktikyang tidak jujur dan pula bertentangan dengan norma-normakepatutan dalam perdagangan.

Para produsen dan pedagang di negara manapun mereka berada, membangun reputasi dan kepercayaan masyarakat kepada usaha mereka melalui merek yang dipergunakan. Dalam hubungan ini, para pesaing yang tidak jujur akan dapat terlalu lama mempertahankan kedudukannya di pasar yang diperoleh secara curang, apabila mereka dibiarkan menghancurkan daya pembeda dari merek-merek yang digunakan untuk mengenali kegiatan perdagangan yang menandai barang-barang dagangan, dengan cara meniru merek dan melanggar hak orang lain atas merek-merek tersebut. Akhirnya bukan hanya pengusaha yang jujur sajayang dirugikan, tetapi juga para konsumen. Oleh karena itu, para konsumen di manapun mereka berada, harus dilindungi terhadap penipuan yand dilakukan dengan cara memalsukan merek yang sudah dikenal oleh mereka sebagai merek dari barang-barang yang bermutu baik.

Dapat disimpulkan bahwa tujuan perlindungan hukum atas merek adalah untuk sedapat mungkin secara seimbang melindungi kepentingan semua pihak, yaitu para produsen di satu pihak dan para konsumen di pihak lainnya. ${ }^{17)}$

15 ) Ibid, hlm 9.

16) Suyud Margo, Hak Milik Industri: Pengaturan dan Praktek di Indonesia, Graha Indonesia, Bogor, 2011, hlm 79

17) Ibid, hlm 50 


\section{PEMBAHASAN}

\section{Analisis Terhadap Sengketa Merek Terhadap Produk Terdaftar Di Direktorat Jenderal Hak Kekayaan Intelektual Berdasarkan Undang-Undang Nomor 20 Tahun 2016 Tentang Merek Dan Indikasi Geografis.}

Kekayaan Intelektual merupakan suatu hak yang berasal dari hasil kreatif suatu kemampuan daya pikir manusia yang diekspresikankepada khalayak umum dalam berbagi bentuk yang bermanfaat dalammenunjang kehidupan manusia yang memiliki nilai ekonomis. Bentuknyata dari kemampuan tersebut misalnya dalam bidang teknologi, ilmupengetahuan, seni dan sastra.

Merek merupakan salah satu hal yang terpenting di dalam duniaperdagangan. Merek dapat menunjukan identitas perusahaan kepadamasyarakat luas. Sebuah merek memberikan cerminan mengenaibarang yang dijual di pasaran. Mengembangan merek membutuhkandana dan perjuangan yang tidak sedikit. Perusahaan banyak yangmenjaga reputasi mereknya, karena mereka beranggapan bahwa merekmerupakan reputasinya juga.

Reputasi merek yang semakin baik maka banyak juga masalah yangtimbul. Persaingan usaha yang curang merupakan pemasalahan yangpaling sering dihadapi oleh para pengusaha. Persaingan usaha timbulkarena para pelaku usaha tidak mau bersusah payah untuk membangunusahanya dan kemudian menginginkan hal yang instan untukmendapatkan untung yang besar. Pelaku usaha tersebut melakukanpemalsuan atau peniruan merek untuk mendapatkan reputasi yangsama dengan merek yang ditirunya.

Pada dasarnya sebuah merek memiliki persyaratan untukdidaftarkan. Sistem administrasi merek begitu penting karena hak atas merek adalah hak khusus yang diberikan oleh pemerintah atau negara kepada pemilik merek untuk menggunakan merek tersebut atau memberi izin pihak lain untuk menggunakannya, karena itu merek harus didaftarkan di Direktorat Jenderal Hak Kekayaan Intelektual. Pendaftaran sangat penting artinya bagi konsumen, karena konsumen akan membeli merek (cap, simbol, lambang, dan sebagainya) yang tentunya memiliki kualitas dan aman untuk dikonsumsi.

Kasus peniruan merek sering sekali terjadi seperti kasus Mawar Super Laundry dan Logo Superman di mana dalam kasus ini pihak pendaftar merek pertama yang kalah dalam persidangan, akan tetapi Pendaftaran atas merek merupakan salah satu bentuk perlindungan dari Undang-Undang Merek, karena sistem yang digunakan di Indonesia adalah first to file principle, siapa yang mendaftar pertama maka yang bersangkutan berhak atas merek tersebut dan akan mendapatkan hak esklusifnya dengan konsekuensi tidak ada seorangpun yang boleh menggunakan merek tersebut untuk kepentingan komersial dari hak ekslusif tersebut tanpa seizin pemilik atau pemegang hak merek.

Pemilik merek terdaftar pertama seperti kasus Mawar super laundry dan Logo Superman dikuatkan dalam pasal 3 Undang-Undang Merek dan Indikasi Geografis, menyatakan bahwa hak atas merek diperoleh setelah merek tersebut terdaftar. Dengan kata lain, diperolehnya hak atas merek adalah sebagai satu konsekuensi telah didaftarkan merek tersebut pada Kantor Direktorat Jendral Hak Kekayaan Intelektual. Pendaftaran adalah syarat mutlak bagi seseorang jika merek tersebut diakui secara sah bahwa ia adalah pemilik dari merek tersebut. Tanpa pendaftaran, maka tidak Perlindungan merek tersebut dan juga perlindungan yang diberikan atas merek tersebut.

Sengketa merek mawar super laundry di mana pemilik pertama Siti Hardita Sundari dengan nomor pendaftaran IDM000612703 yang kalah dalam putusan pertama dan kasasi dari pihak penggugat Siti Wardah dengan gugatan itikad tidak baik, dalam persidangan tersebut prinsip first to file diabaikan akan tetapi pendaftar atas merek merupakan salah satu bentuk perlindungan dari pasal 3 Undang-Undang nomor 20 Tahun 2016 Tentang 
Merek dan Indikasi Geografis siapa yang mendaftarkan pertama maka yang bersangkutanlah yang berhak atas merek tersebut dan akan mendapatkan hak ekslusif tidak ada seorangpun yang boleh menggunakan merek tersebut.

Permohonan pendaftaran merek tergugat telah dikabulkan oleh Direktorat Jenderal Hak Kekayaan Intelektual dan telah didaftarkan pada tanggal 16 April 2018 dalam kelas barang 3 dengan No. Pendaftaran IDM000612703, hal ini membuktikan bahwa tergugat adalah memang merupakan pemilik atas merek Mawar super laundy adapun yang seharusnya menjadi pertimbangan majelis Hakim Pengadilan Niaga adalah adanya buktibukti yang kuat yang dapat mendukung dalil gugatan tergugat bahwa tergugat merupakan pemilik satu-satunya merek Mawar Super laundry. Maka dari itu majelis Hakim kurang tepat dalam memberikan pertimbangkannya yang berakibat terhadap putusan, karena yang memenuhi merek yang sesungguhnya adalah Siti Hardita Sundari hal ini berperinsip pada first to file prinsip terhadap Siti Wardah. Dalam hal ini hakim mengabaikan pasal 3 Undang-Undang Nomor 20 Tahun 2016 Tentang Merek dan Indikasi Geografis.

Logo Superman di mana pemilik merek terkenal dan pendaftar pertama pihak DC Comics menggugat pihak PT Marxing Fam Makmur dengan itikad tidak baik dan memiliki persamaan pada pokoknya dengan wafer logo Luperman buatan PT Marxing Fam Makmur di mana pihak PT Marxing Fam Makmur menang dalam persidangan putusan pertama dan kasasi. Untuk kasus logo Superman ini sengketa merek terjadi akibat kelalaian dari pihak Direktorat Jendral Hak Kekayaan Intelektual yang mengeluarkan sertifikat terhadap merek logo Superman dari pihak PT Marxing Fam Makmur. Di mana pihak DC Comics sebagai pemilik dan pihak pertama pendaftar dan mereknya merupakan merek terkenal, maka dari itu Direktorat Jendral Hak Kekayaan Intelektual telah melanggar pasal 21 ayat (1) huruf b dan c Undang-Undang Nomor 20 Tahun 2016 Tentang Merek dan Indikasi Geografis.

Pentingnya merek adalah identitas produk itu sendiri. Dengan adanya merek akan meningkatkan daya saing dan sangat mempengaruhi perilaku konsumen dalam membeli suatu produk. Oleh sebab itu, para pebisnis maupun pelaku Usaha Kecil Menengah (UKM) harus memperhatikan dengan seksama terhadap faktor ini, merek yang unik dan berbeda dengan yang lain akan membuat konsumen mengingat produk kita, menggaet konsumen, agar konsumen tertarik untuk membeli produk anda dan dengan nama yang unik dan berbeda, apalagi misal menggunakan bahasa yang familiar dengan ingatan akan semakin memudahkan branding/merk melekat dalam ingatan konsumen.

Fungsi merek sendiri sebagai sebagai daya pembeda dari suatu produk barang atau jasa antara satu produsen dengan produsen lainnya,sebagai daya pembeda dari suatu produk barang atau jasa antara satu produsen dengan produsen lainnyadari suatu perusahaan dengan barang dan/atau jasa perusahaan lain, sebagai penghubung suatu barang dan jasa yang bersangkutan dengan produsennya, sebagai penentu kualitas dari suatu barang dan/atau jasa, sebagai sarana promosi dalam dunia perdagangan, untuk menggambarkan jaminan kepribadian dan reputasi atas suatu barang dan jasa hasil usaha sewaktu diperdagangkan, sebagai sarana pengendali pasar suatu merek yang mempunyai reputasi akan mempunyai nilai yang tinggi dan berharga apalagi sudah dikenal baik oleh konsumen oleh karenanya pendafataran merk sangat diperlukan oleh para pengusaha untuk melindungi hak kekayaan intelektualnya.

Merek adalah bentuk perlindungan Hak Kekayaan Intelektual yang memberikan hak eksklusif bagi pemilik merek terdaftar untuk menggunakan merek tersebut dalam perdagangan barang dan/atau jasa, sesuai dengan kelas dan jenis barang/jasa untuk mana merek tersebut terdaftar.Satu hal yang perlu dipahami adalah, pendaftaran merek untuk memperoleh hak merek bukan berarti ijin untuk menggunakan merek itu sendiri. Siapapun berhak memakai merek apapun didaftar ataupun tidak sepanjang tidak sama dengan merek 
terdaftar milik orang lain di kelas dan jenis barang/jasa yang sama. Hanya saja, dengan merek terdaftar, si pemilik merek punya hak melarang siapapun untuk menggunakan merek yang sama dengan merek terdaftar miliknya, tentunya untuk kelas dan jenis barang/jasa yang sama.

\section{Upaya Penanggulangan Sengketa Merek Berdasarkan Undang-Undang Nomor 20 Tahun 2016 Tentang Merek dan Indikasi Geografis.}

Sengketa merek dapat terjadi apabila ketentuan dalam pendaftaran merek dilanggar, siapapun dapat mengalami hal tersebut dan mengakibatkan masalah pada bisnis seperti cotohnya kasus sengketa Mawar super laundry dan sengketa merek Logo Superman. Maka dari itu diperlukan perlindungan bagi pemegang merek.

Merek terdaftar akan lebih aman dan mempunyai perlindungan hukum, perlindungan hukum tersebut dapat berupa perlindungan yang bersifat preventif dan represif.

1. Perlindungan hukum preventif.

Preventif yaitu perlindungan sebelum terjadinya tindak pidana atau pelanggaran hukum. Sebagaimana dalam hal ini sangat bergantung pada pemilik merek untuk mendaftarkan mereknya agar mendapatkan perlindungan hukum dalam sengketa merek. Pendaftaran merek merupakan langkah untuk menghindari terjadinya sengketa merek diatur dalam pasal 3 Undang-Undang Nomor 20 Tahun 2016 Tentang Merek dan Indikasi Geografis, kemudian Mengenai syarat dan tata cara permohonan pendaftaran merek di atur dalam Undang- undang No. 20 Tahun 2016 tentang merek dan indikasi geografis tepatnya dalam pasal 4 sampai dengan pasal 8 . Dalam Undang-Undang Merek dan Indikasi Geografis.

Sistem pendaftar konstitutif disebut juga first to file principle. Yang artinya, merek yang didaftar adalah yang memenuhi syarat dan sebagai yang pertama. Tidak semua merek dapat didaftarkan. Merek tidak bisa didaftar atas dasar permohonan yang diajukan oleh pemohon yang beretikad tidak baik. Pemohon beretikad tidak baik adalah pemohon yang mendaftarkan mereknya secara tidak layak dan tidak jujur, ada niat tersembunyi misalnya "menunggangi", meniru, atau menjiplak popularitas menimbulkan kompetisi bisnis yang tidak sehat dan "membuayai" atau menyesatkan konsumen. Yang dapat mendaftarkan merek adalah orang atau badan hukum.

Tidak semua permohonan pendaftaran merek dikabulkan olehDirektorat Hak Kekayaan Intelektual karena permohonan pendaftaranmerek dapat menghadapi tiga kemungkinan :

1. Tidak dapat didaftarkan.

2. Harus ditolak pendaftarannya.

3. Diterima/didaftarkan.

Ketentuan Undang-undang Nomor. 20 Tahun 2016 tentang Merek dan Indikasi Geografis lanjut apa saja yang tidak dapat dijadikan suatu merek atau yang tidak dapat didaftarkan sebagai suatu merek. Berdasarkan Pasal 20 dan pasal 21 Undangundang Nomor 20 Tahun 2016 Tentang Merek dan Indikasi Geografis tidak dapat didaftarkan dan ditolaknya pendaftaran apabila mengandung salah satu.

2. Perlindungan hukum represif.

Ada yang menganggap bahwa merek hanya perlu didaftarkan ketika sudah menjadi bisnis besar. Padahal, saat hendak merintis usaha hingga tiba pada level Usaha Kecil Menengah (UKM), merek merupakan unsur yang penting. Salah satu 
kegunaannya adalah sebagai identitas sebuah produk. Jika merek didaftarkan orang lain Merek yang telah sah menjadi milik Anda memiliki kekuatan hukum. Artinya, Anda dapat mengajukan tuntutan melalui pengadilan jika ada orang lain yang menggunakan merek Anda. Ketika orang lain menggunakan merek Anda, sebagai pemilik merek asli, ada beberapa hal yang bisa dilakukan.

Upaya penanggulangan terhadap sengketa merek represif adalah Penyelesaian sengketa merek dapat ditempuh secara khusus dalam Undang-Undang Nomor 20 Tahun 2016 tentang Merek dan Indikasi Geografis.

1. Gugatan Perdata.

2. Gugatan Pidana.

3. Administratif

Undang-Undang Merek memberikan pilihan penyelesaian hukum bagi pemegang merek yang haknya dilanggar oleh pihak lain. Berikut ini mekanisme penyelesaian bagi pemegang merek yang ingin mempertahankan haknya:

1. Gugatan perdata, dapat dilakukan berdasarkan ketentuan pasal 83 UndangUndang Nomor 20 Tahun 2016 Tentang Merek dan Indikasi Geografis. Dapat mengajukan gugatan terhadap pihak lain yang secara tanpa hak menggunakan merek yang mempunyai persamaan pada pokoknya atau seluruuhnya. Pemegang merek berhak mengajukan gugatan ganti rugi kepada pengadilan niaga atas kerugian yang dialami dan memohon kepada pengadilan niaga agar memerintahkan penghentian semua perbuatan yang berkaitan dengan penggunaan merek tersebut.

2. Tuntutan pidana, ketentuan pidana pelanggaran merek diatur di dalam pasal 100-103 Undang-Undang Nomor 20 Tahun 2016 Tentang Merek dan Indikasi Geografis. Tanpa hak menggunakan merek yang sama pada keseluruhannya dengan merek terdaftar dengan pidana penjara paling lama 5 (lima) tahun penjara atau pidana denda paling banyak Rp. 2.000.000.000.00 (dua milliar rupiah). Pengajuan gugatan perdata tetap bisa dilakukan bersama tuntutan pidana. Proses perdata tidak menggugurkan hak negara untuk melakuan tuntutan pidana terhadap pihak yang memiliki iktikad tidak baik tersebut.

3. Penyelesaian secara administratif bila terjadi pelanggaran merek dapat dilakukan melalui kewenangan administrasi negara, yaitu di antaranya melalui Kewenangan Pabean Standar Industri, Kewenangan Pengawasan Badan Penyiaran, dan Kewenangan Pengawasan Standar Periklanan. Sanksi administratif yang dapat dikenakan kepada pihak yang telah menggunakan merek secara tanpa hak, diantaranya dapat berupa tindakan larangan impor, larangan yang berkaitan dengan izin bagi peredaran barang yang menggunakan merek terdaftar milik pihak lain maupun larangan terhadap iklan merek yang menyesatkan konsumen.

Menurut penulis sengketa merek diselesaikan melalui gugatan perdata antara Mawar super laundy dan Logo Superman telah tepat diselesaikan dengan jalur gugatan perdata. 


\section{PENUTUP}

\section{Kesimpulan}

Pada sengketa merek "Mawar Super Laundry" dan "Logo Superman" Dimana pihak pendaftar pertama berhak mendapatkan perlindungan hukum sebagaimana dalam pasal 3 Undang-Undang Nomor 20 Tentang Merek dan Indikasi Geografis yang menyatakan hak atas merek diperoleh setelah merek tersebut terdaftar dan sesuai dengan Sistem pendaftar first to file principle. Yang artinya, merek yang didaftar adalah yang memenuhi syarat dan sebagai yang pertama.

Upaya penanggulangan terhadap sengketa merek dapat dilakukan dengan 2 upaya yaitu preventif dan represif . prefentif dapat dilakukan dengan cara pendaftaran ke Direktorat Jendral Hak Kekayaan Intelektual sedangkan represif dapat dilakukan dengan cara gugatan perdata, pidana, dan Administratif.

\section{Saran}

Direktorat Jenderal Hak Kekayaan Intelektual harus lebih selektif dalam melakukan penerimaan permohonan pendaftaran merek agar tidak terjadi sengketa merek seperti Mawar Super Laundry dan Logo Superman. Direktorat Jenderal Hak Kekayaan Intelektual selaku penerima pendaftaran merek, seharusnya dalam menerima merek harus mempertimbangkan syarat-syarat prosuder pendaftaran merek dan juga ketentuanketentuan yang terdapat dalam undang-undang yang mengatur agar tidak menimbulkan masalah jika ada merek yang terdaftar tidak sesuai dengan ketentuan-ketentuan yang berlaku. Setelah adanya putusan atas sengketa merek tersebut seharusnya diumumkan kepada masyarakat melalui media massa tidak hanya media online saja. Ini dimaksudkan untuk memberikan pengetahuan kepada masyarakat atas sengketa merek agar tidak menimbulkan kebingungan publik serta diharapkan dapat mengurangi kemungkinan masalah sengketa merek seperti ini terulang kembali.

\section{DAFTAR PUSTAKA}

Ahmedi miru, Hukum Merek, Rajawai Pers, Jakarta, 2015.

Casavera, 15 Kasus Sengketa Merek di Indonesia, Graha Ilmu, Yogyakarta, 2009.

Daniel Suryana, Sejarah dan Perkembangan Hak Kekayaan Intelektual Indonesia, dansur, Jakarta, 2001

Irsalina Julia Ermin, “ Tinjauan Hukum Terhadap Pendaftaran Merek yang MNugrahaenggunakan Kata Milik Umum “, Pustaka bani, Makassar, 2016.

Iswi hariyanti (et al), hak kekayaan intelektual sebagai jaminan kredit, penerbit andi yogyakarta, 2018.

Jonaedi Efendi, Jhonny Ibrahim, Metode Penelitian Normatif dan Empiris, prenada group, Jakarta, 2018.

Suyud Margono, Hak Milik Industri: Pengaturan dan Praktik di Indonesia, Ghalia Indonesia, Bogor. 2011,

Pipin Syarifin, Peraturan Hak Kekayaan Intelektual di Indonesia,, Pustaka Bani Quraisy, Bandung, 2004.

Tomi Suryo Utomo, Hak Kekayaan Intelektual di Era Global, Graha Ilmu, Yogyakarta, 2010.

Tim Lindsey ( et al ), hak kekayaan intelektual Suatu Pengantar, Asian Law Group pty. \& Penerbit P.T. Alumni,Bandung 2006. 